\title{
PERFORMANCE ANALYSIS OF STARTUP ENTREPRENEURS PROGRAMS
}

\author{
Harry Yulianto \\ Sekolah Tinggi Ilmu Ekonomi YPUP Makassar, Jl. Andi Tonro No. 17, (0411) 854974 \\ Program Studi Manajemen, Sekolah Tinggi Ilmu Ekonomi YPUP Makassar \\ e-mail: harryyulianto.stieypup@gmail.com
}

\begin{abstract}
An aims of this study was analyzed the performance of the Startup Entrepreneurs Program. The design of this study was quantitative by using a descriptive approach. This research data was secondary data obtained from the Deputy for Financing, the Ministry of Cooperatives and Small and Medium Enterprises. Data collection techniques using document studies. The data analysis technique uses quantitative descriptive. The results of this study: an increase in the distribution of aid recipients in the border areas by 91\%; the realization of the number of beneficiaries of the Startup Entrepreneurs Program exceeding the target; women who received the Startup Entrepreneurs Program increased by $165 \%$ if compared to 2017; the growth in the field of business beneficiaries of the Startup Entrepreneurs Program experienced a significant increase in the culinary business sector; the quantity of labor absorption shows an increase in labor absorption of 101\% compared to 2017; and the allocation of assistance for the Startup Entrepreneurs Program has been spread evenly to all provinces in Indonesia.
\end{abstract}

Keywords: Performance, Program, Startup Entrepreneurs (SE).

Abstrak

Penelitian ini bertujuan menganalisis kinerja Program Wirausah Pemula. Desain penelitian ini adalah kuantitatif dengan menggunakan pendekatan deskriptif. Data penelitian ini adalah data sekunder yang diperoleh dari Deputi Bidang Pembiayaan, Kementerian Koperasi dan Usaha Kecil dan Menengah. Teknik pengumpulan data menggunakan studi dokumen. Teknik analisis data menggunakan deskriptif kuantitatif. Hasil penelitian ini:adanya peningkatan sebaran wilayah penerima bantuan pada daerah perbatasan sebesar 91\%; realisasi jumlah penerima bantuan Program Wirausaha Pemula melebihi target; wanita penerima bantuan Program Wirausaha Pemula mengalami peningkatan sebesar 165\% apabila dibandingkan tahun 2017; pertumbuhan bidang usaha penerima bantuan Program Wirausaha Pemula mengalami kenaikan yang signifikan pada bidang usaha kuliner; kuantitas serapan tenaga kerja menunjukkan terdapat kenaikan serapan tenaga kerja sebesar 101\% jika dibandingkan tahun 2017; serta alokasi bantuan Program Wirausaha Pemula sudah tersebar secara merata ke seluruh propinsi di Indonesia.

Kata kunci: Kinerja, Program, Wirausaha Pemula (WP).

\section{INTRODUCTION}

For the developing countries, entrepreneurial development which in the beginning can be a major factor in a country's economic growth. It cause development still relies on capital formation (domestic and foreign), entrepreneurial formation was needed, especially for beginners. Entrepreneurship has a role in national development and development, both external and internal. Externally, the entrepreneur becomes a provider of employment for job seekers. With the employment of existing employment opportunities provided by entrepreneurs, the national payment rate will be even greater. Internally, entrepreneurs in reducing the level of trust in others, can increase self-confidence, and increase purchasing power for entrepreneurs (Darwanto, 2012).

Entrepreneurs have a role in the economy and national development, both externally and internally. Externally, the entrepreneur acts as a provider of employment for job seekers. With the absorption of labor by existing and provided employment opportunities by 
entrepreneurs, the national unemployment rate will be even less. Internally, entrepreneurs in reducing the level of dependence on others, can increase selfconfidence, and increase purchasing power for businesses.

With the decline in the unemployment rate, it can have a positive impact on rising income per capita, people's purchasing power, and the growth of the national economy. In addition, with the growth of the per capita economy, it can have an impact on the decline in crime it was usually caused by high unemployment (Rahim \& Basir, 2019).

The current number of entrepreneurs in Indonesia has only reached $3.1 \%$ of the total population. Ideally, the entrepreneurial ratio were $4 \%$ in order to encourage national economic growth (Budi \& Fensi, 2018). Although the entrepreneurial ratio in Indonesia was already above international standards, which was equal to $2 \%$, Indonesia needs to improve its performance to pursue the achievements of neighboring countries. Singapore has reached $7 \%$, while Malaysia was at the level of $5 \%$. If calculated with the population of Indonesia around 260 million people, then the number of national entrepreneurs has only reached 8.06 million people.

In order to grow new entrepreneurs and support job creation and poverty reduction, the Ministry of Cooperatives and Small and Medium Enterprises was organizing the Startup Entrepreneurs Program. Startup entrepreneurs were individuals who have businesses and/or startup that have the potential to develop their business capacity (Yulianto, 2017).

The government has a role in providing assistance and/or providing financial assistance for startup entrepreneurs. The purpose of financial assistance in the form of financial assistance for startup entrepreneurs was to reconstruct the business to be more productive, so that it can make the business more competitive and competitive (Yulianto \& Iryani, 2018)

The program provides assistance in the form of grants to startup entrepreneurs for micro scale. The total government assistance fund for WPs in the form of cash grants were IDR 10 million (ten million rupiah) and a maximum of IDR 12 million (twelve million rupiah) (KUKM, 2018).

The background of the Startup Entrepreneurs Program was to promote and cultivate entrepreneurship among the community, through the provision of government assistance in the form of startup capital to startup entrepreneurs (individuals). Providing grants to startup entrepreneurs as a form of support for startup. One of them was by strengthening the business after receiving assistance. The potential of SMEs that have not been managed optimally, on the contrary many SMEs actors (owners) actually often experience internal problems, making it difficult to develop and compete, both among SMEs and with large producers (Yulianto, 2016).

From 2010 to 2018, the Ministry of Cooperatives and Small and Medium Enterprises has provided grants to startup entrepreneurs spread across 34 provinces. The Startup Entrepreneurs Program aims to encourage economic development in the Disadvantaged Regions, Border Regions, Special Economic Regions (KEK), and Low-income Intergroup Regions through job creation, poverty reduction, reducing income inequality, and increasing sustainable livelihoods.

Government assistance for startup entrepreneurs was expected to increase the productivity of micro and small businesses, so they can move up the class. It means novice entrepreneurs must be able to look for opportunities and expand their businesses to a higher scale (Yulianto \& Iryani, 2018). Grant assistance was based on the fact that there were still many SMEs that were not yet included in the bankable category. These conditions resulted in efforts to 'improve class' the UMKM still needs to be done. Therefore, grants as a solution for SMEs that are not bankable, so that business assistance and empowerment were also provided. In this regard, this study will analyze the performance of the Startup Entrepreneurs Program. 
Based on the description, an aims of the study was to analyze of performance program. Performance indicators of performance program were measured by: 1) distribution of beneficiary areas; 2) number of beneficiaries; 3) gender proportion of beneficiaries; 4) the business field of the recipient of assistance; 5) quantity of labor absorption; and 6) allocation of grant recipient funds. The scope of this research is only to analyze the feasibility documents for startup entrepreneurs in 2017 (KUKM, 2017) and 2018 (KUKM, 2018).

\section{RESEARCH METHODS}

The design of this study was quantitative by using a descriptive approach. The data of this study were secondary data, namely data obtained from the second party (Yulianto, 2016). Secondary data were obtained from the Deputy for Financing at the Ministry of Cooperatives and Small and Medium Enterprises.
Data collection techniques using document studies, namely data collection techniques that are not addressed directly to research subjects, but examine various documents as material for analysis (Yulianto \& Iryani, 2018). Data analysis techniques using quantitative descriptive, which describes the data that has been collected (Sugiyono, 2015).

\section{RESULTS AND DISCUSSION \\ Distribution of beneficiary areas}

In the provisions of the Technical Guidelines for Government Assistance for Startup Entrepreneurs, assistance provided by the government in the context of enhancing and developing business start-up entrepreneurs to support the development of the Disadvantaged Regions, Border Regions, Special Economic Regions (KEK), and Low-income Intergroup Regions (KUKM. (2018).

Figure 1. Distribution of beneficiary areas

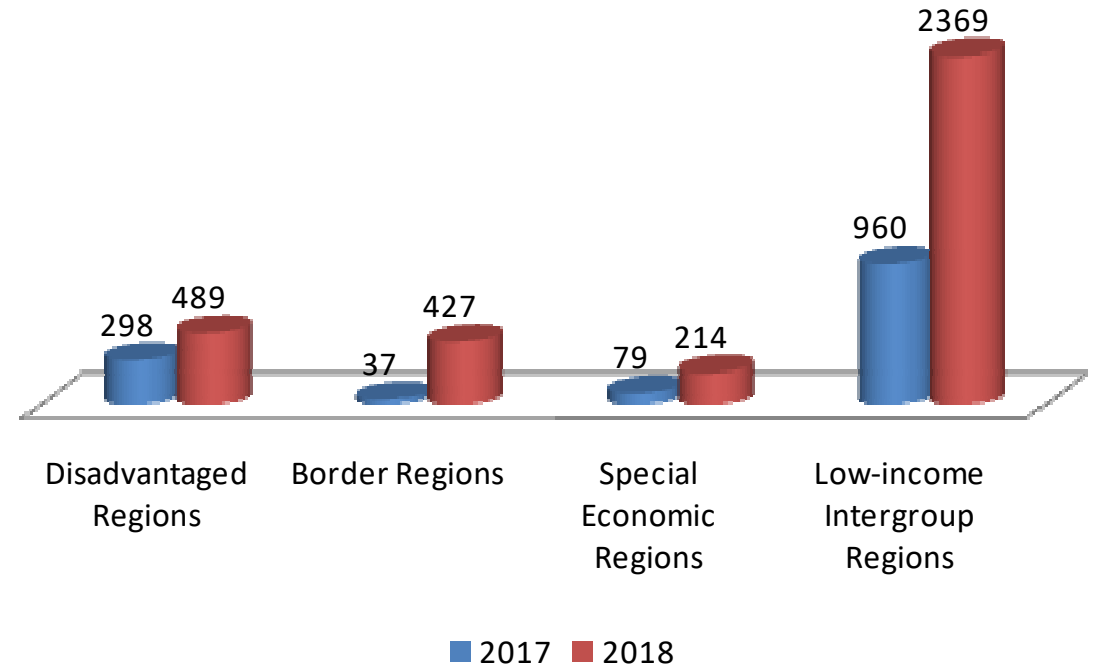

Source: processed data (2019).

Figure 1 indicates the distribution area of the Startup Entrepreneurs Program beneficiaries has fulfilled the provisions in the Startup Entrepreneurs Program Technical Guidelines. There was an increase from 2017 to 2018, where the biggest increase in the Border Areas was $91 \%$.

\section{Number of beneficiaries}

The criteria to get assistance from the Startup Entrepreneurs Program: 1) having a business startup that has potential for growth, the business has been running for a minimum of 6 months and a maximum of 3 years; 2) have never received similar financial assistance from the Ministry of 
Cooperatives and Small and Medium Enterprises, as evidenced by a written statement from the person concerned; 3) maximum age of 45 years; 4) minimum junior high school education or equivalent; 5) has a valid identity card in the form of an Identity Card (KTP); 6) has business legality in the form of a Micro Small Business Permit (IUMK) or Domicile Certificate from the local government office; 7) has a Taxpayer Identification
Number (NPWP) which was still active on behalf of the prospective beneficiary; 8 ) has an Entrepreneurship Certificate a maximum of 2 (two) years prior to the current fiscal year; 9) have a Business Plan; 10) have an active savings account in the name of the prospective beneficiary with a savings value above the minimum balance; and 11) no status as Civil Servants (PNS), members of the TNI or POLRI.

\section{Figure 2. Comparison of number of business proposals}

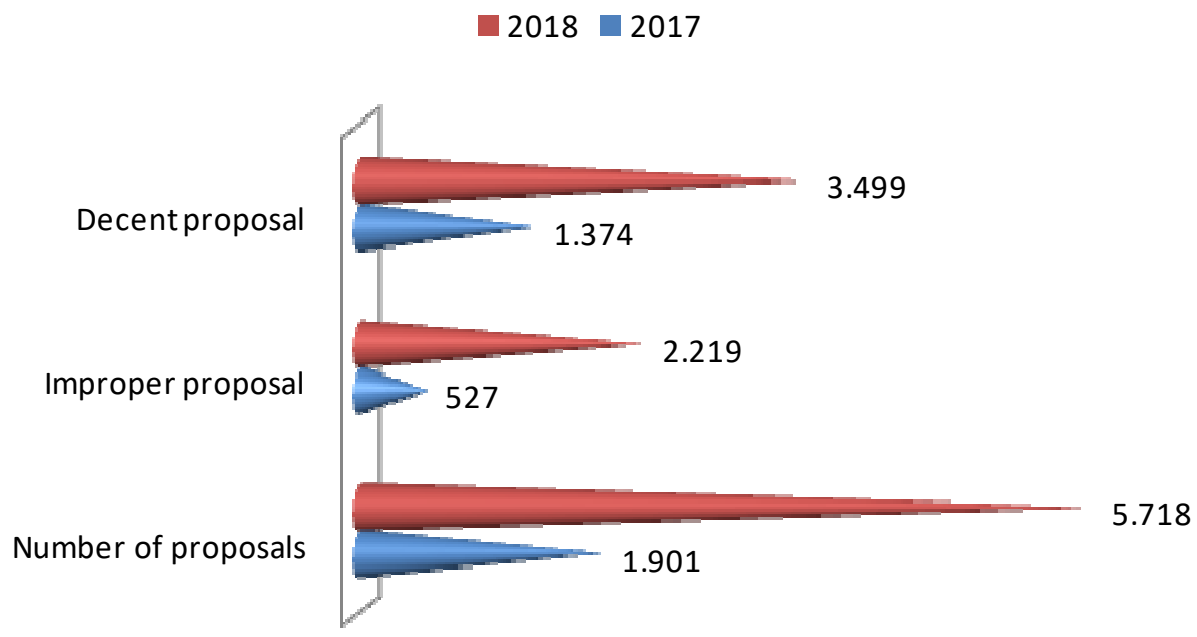

Source: processed data (2019).

Figure 2 indicates the proposals submitted in 2018 increased by $67 \%$ compared to 2017. The number of eligible proposals in 2018 increased by $61 \%$ compared to 2017. It means an increase in beneficiaries for the Startup Entrepreneurs Program, which in 2017 of 1,374 people increased to 3,499 in 2018.

Figure 3. Target achievements

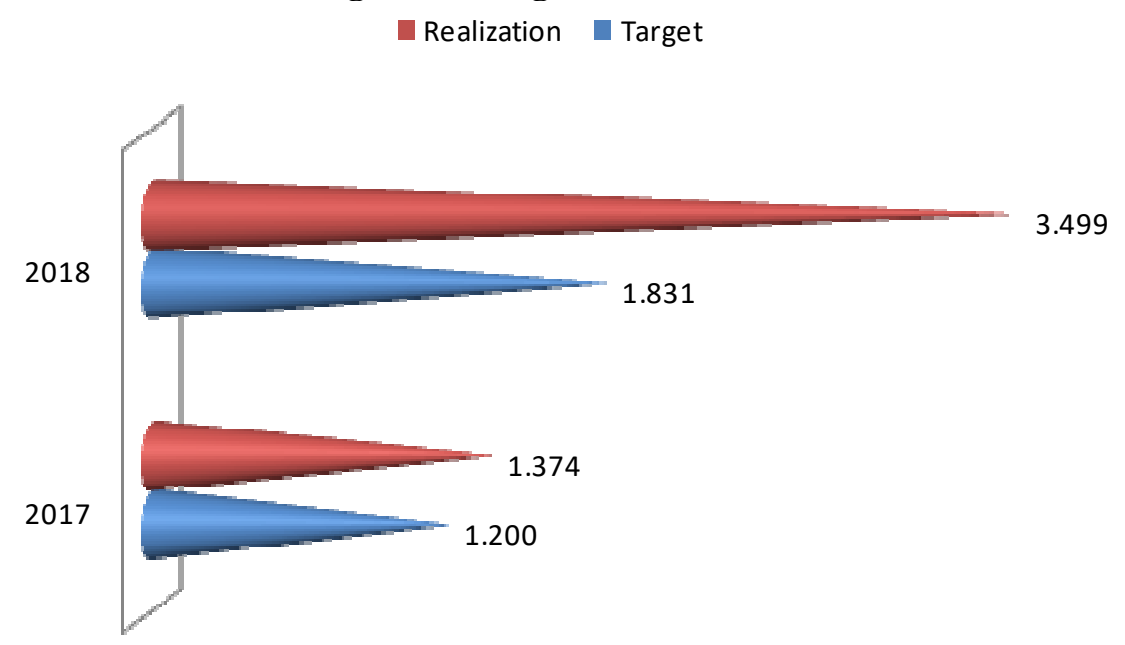

Source: processed data (2019). 
AkMen

Figure 3 indicates the realization of the number of beneficiaries of the Startup Entrepreneurs Program exceeded the target set. In 2017 the realization was above the target of $115 \%$ from 1,200 . whereas, in 2018 realization increased by $191 \%$ from the target of 1,831 .

\section{Gender proportion of beneficiaries}

Figure 4 indicates the gender proportion of women beneficiaries of the Startup Entrepreneurs Program in 2018 increased by $165 \%$ when compared to 2017.

Figure 4. Proportion of gender beneficiaries
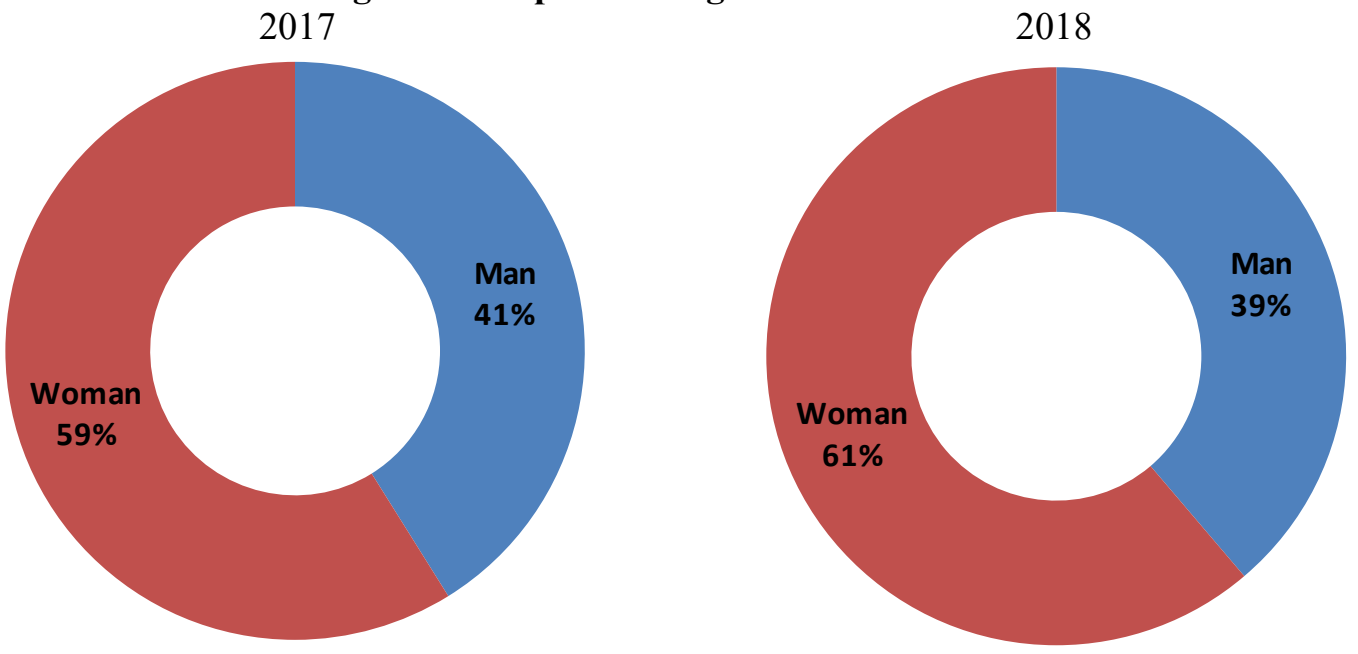

Source: processed data (2019).

Based on Figure 4, most of the beneficiaries of the Startup Entrepreneurs Program were women. When compared to men, women have the tenacity to run their businesses and the results of their efforts can provide additional income for their households.

\section{Business fields of beneficiaries}

The business sectors receiving the assistance of the Beginner Entrepreneurial Program are grouped into: 1) services; 2) trade; 3) other innovative; 4) agriculture; 5) fisheries; 6) animal husbandry; 7) convection and clothing; 8) crafts; and 9) culinary.

\section{Figure 5. Business fields of beneficiaries}

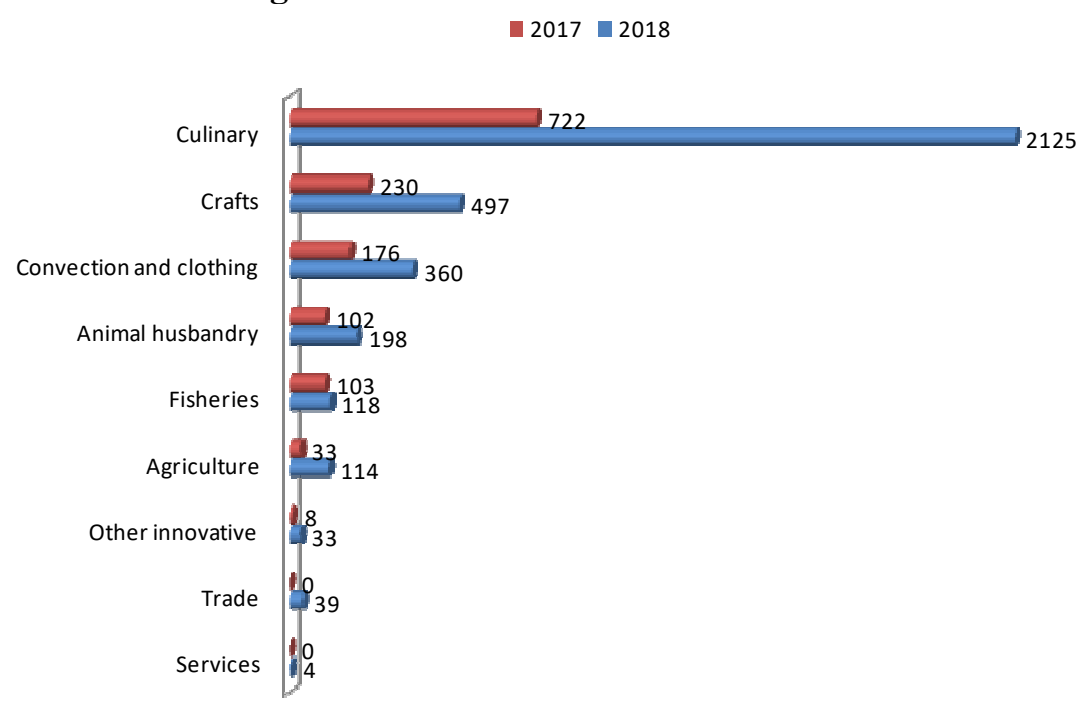


Source: processed data (2019).

Figure 5 indicates the growth in the field of business receiving the Startup Entrepreneurs Program experienced a significant increase in the culinary business sector. It shows culinary was not just fulfilling food needs, but also has become a life style now. Therefore, business development in the culinary field was able to contribute $41.4 \%$ of the total Gross Domestic Product (GDP) of Indonesia's creative economy.

Transportation-based application platform trends also contribute to facilitate food ordering and delivery, so that it becomes one of the factors driving the growth of SMEs, especially in the culinary field. The growth of culinary business, provides opportunities and challenges for novice entrepreneurs to continue to innovate and provide quality products, which were liked and in accordance with the needs of the community. Product uniqueness and enjoyment of taste were the keys to survive in the midst of culinary business competition.

\section{Quantity of labor absorption}

Employment absorption was the number of workers produced from business management carried out by the recipients of the Startup Entrepreneurs Program.

\section{Figure 6. Quantity of labor absorption}

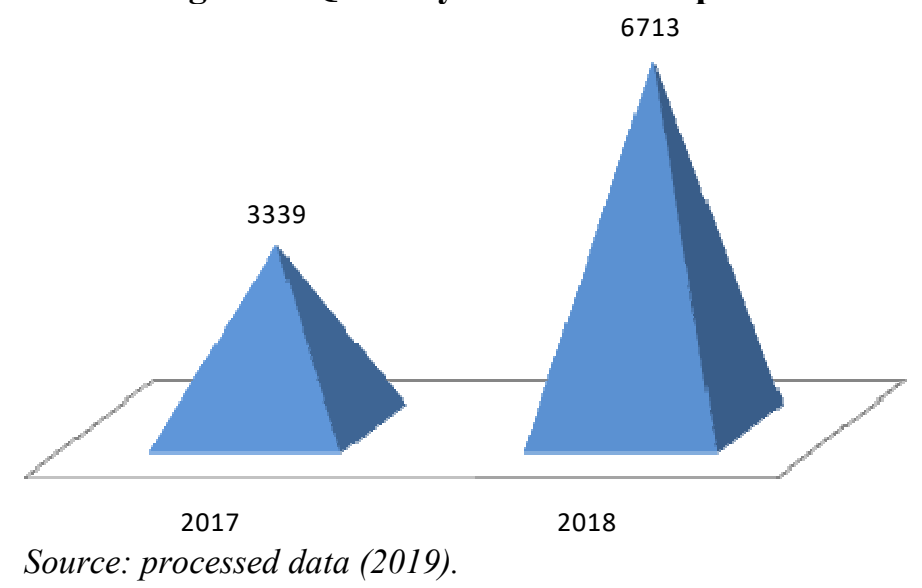

Figure 6 indicates the Startup Entrepreneurs Program has an impact on the quantity of labor absorption. In 2017 the workforce absorption was 3339 people, and in 2018 it increased to 6713 people. It means there was an increase in labor absorption of $101 \%$ compared to 2017 .

$100 \%$ government assistance was given to productive sector businesses which have an impact on increasing national GDP. SMEs in the national economy have a very important role. This is indicated by the contribution of the SMEs sector to GDP products which increased from $57.89 \%$ to $60.34 \%$ in the last five years. Employment absorption in the SMEs sector increased from $96.99 \%$ to $97.22 \%$ in the same period.
Allocation of grant recipient funds
Government assistance funds given to the recipients of the Startup Entrepreneurs Program were intended to strengthen the start-up capital of WP business in supporting the welfare of the community. 
Figure 7. Total allocation of grant recipient funds

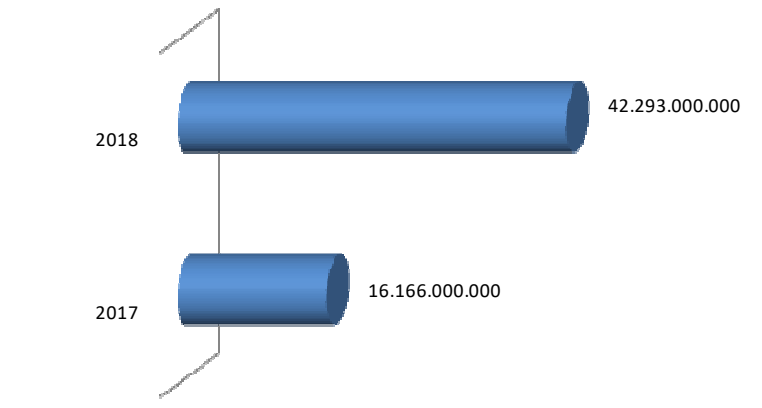

Source: processed data (2019).

Figure 7 indicates there was an increase in budget allocation for the recipients of the Startup Entrepreneurs Program. In 2017 the government allocated a grant of Rp. 16,166,000,000 and in 2018 it was allocated as much as Rp. 42,293,000,000. It means an increase of $162 \%$ if compared to 2017 .

Figure 8. Allocation of Grant Recipient Funds Based on Provincial Distribution (Rp. Million)
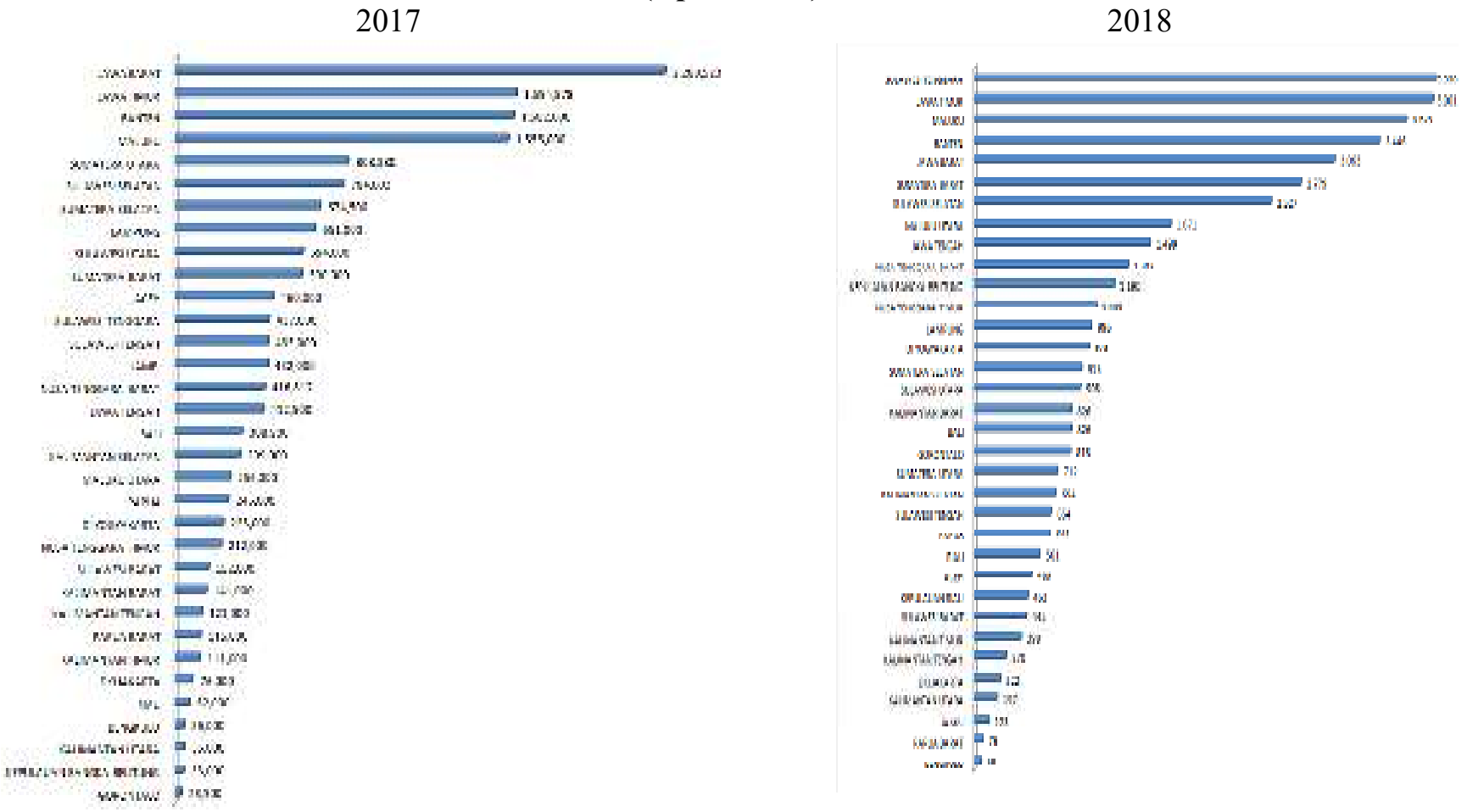

Source: processed data (2019).

Figure 8 indicates the allocation of grant recipient funds based on provincial distribution has changed, where in 2017 the provinces that received aid allocations with the top five positions such as: West Java, East Java, Banten, Maluku and North Sumatra. Meanwhile, in 2018 the provinces that received aid allocations with the top five positions such as: Southeast Sulawesi, East Java, Maluku, Banten and West Java. In general, the allocation of assistance for the Startup Entrepreneurs Program has been spread evenly to all provinces in Indonesia. 
Figure 9. Allocation of grant recipient funds by gender (Rp)

Woman Man

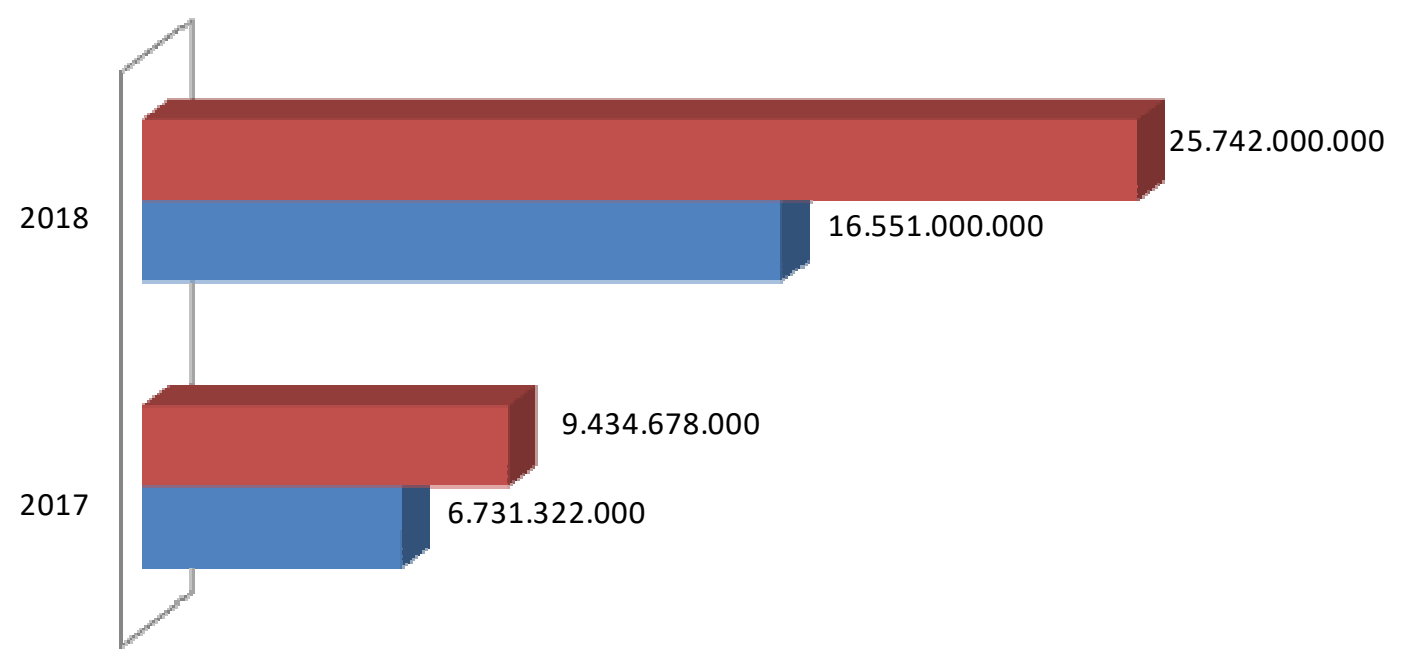

Source: processed data (2019).

Figure 9 shows that the allocation of grant recipients by gender is greater for female recipients compared to men. In 2018 beneficiaries of aid for women increased by $173 \%$ compared to 2017 . This indicates that women have the tenacity and readiness in managing aid funds for business development.

\section{CONCLUSION}

Based on the results and discussion, it can be concluded as follows:

- Distribution of beneficiary areas was in accordance with the provisions of the Technical Guidelines for Government Assistance for Startup Entrepreneurs, which allocate aid funds to support the development of the Disadvantaged Regions, Border Regions, Special Economic Regions (KEK), and Lowincome Intergroup Regions. The results of the discussion showed there was an increase from 2017 to 2018 , where the largest increase was in the Border Areas by $91 \%$.

- The number of beneficiaries shows an increase in beneficiaries of the Startup Entrepreneurs Program, where in 2017 by 1,374 people increased to 3,499 people in 2018. In addition, the realization of the number of beneficiaries of the Startup
Entrepreneurs Program exceeded the established target.

- The gender proportion of beneficiaries among women beneficiaries of the Startup Entrepreneurs Program in 2018 increased by $165 \%$ when compared to 2017.

- The business sectors of aid recipients are grouped into: 1) services; 2) trade; 3) other innovative; 4) agriculture; 5) fisheries; 6) animal husbandry; 7) convection and clothing; 8) crafts; and 9) culinary. The results of the discussion showed that the growth of the business sector beneficiaries of the Startup Entrepreneurs Program experienced a significant increase in the culinary business sector.

- Labor absorption shows an increase in labor absorption of $101 \%$ when compared to 2017.

- Allocation of grant recipient funds shows an increase in the allocation of funds from the government to recipients of the Startup Entrepreneurs Program by $162 \%$ compared to 2017 . In general, the allocation of assistance for the Startup Entrepreneurs Program has been spread evenly to all provinces in Indonesia. In addition, the allocation of grant recipients based on gender is greater for female recipients compared to men. 


\section{RECOMMENDATION}

For government, especially KUKM were recommendation, such as: 1) in the implementation of entrepreneurship training, or technical guidance or internships organized by the central government and regional governments can use the curriculum material on entrepreneurship; 2) the proposal format was carried out by standardization that is simple and easily filled out by entrepreneurs; 3 ) there was a notification to the public about the deadline for entry and the deadline for receipt of proposals; and 4) the proposals if enter the verification stage (for proposals that lack administrative requirements) were given a limit of time and time.

Theoretically, this study only uses quantitative descriptive analysis techniques, where the conclusions were not generalized. For future studies was recommendation use a quantitative approach, in order to obtain quantified conclusions. In addition, further research can use various variables in the apreisal indicators of business proposals as a basis for evaluating the feasibility of WP business proposals, as well as performance indicators for Startup Entrepreneurs Programs.

For the WP, it was recommended to form a joint forum such as a special WP community that can build mutual independence among community members and be able to overcome the various problems faced by WP. It was so WP can organize itself in order to have a wide business network, so that novice entrepreneurs can 'grade up'. And, dor entrepreneurs can run their business better and continue to grow, because the majority of entrepreneurs do not understand how to develop their business (Purwinarti, 2018).

\section{REFERENCES}

Darwanto. 2012. Peran Enrrepreneurship Dalam Mendorong Pertumbuhan Ekonomi dan Peningkatan Kesejahteraan Masyarakat.
Diseminasi Riset Terapan Bidang

Manajemen dan Bisnis Tiingkat

Nasional Jurusan Administrasi

Bisnis Politeknik Negeri

Semarang. 11-24.

http://eprints.undip.ac.id/36859/1/da rwanto-

Peran_Entrepreneur proceed poline s.pdf

Rahim, A.R. \& Basir, B. 2019. Peran Kewirausahaan Dalam Membangun Ketahanan Ekonomi Bangsa.

Economic Resources. 2 (1): 34-39.

Budi \& Fensi, F. 2018. Pengaruh Pendidikan Kewirausahaan Dalam Menumbuhkan Minat Berwirausaha. Jurnal Pengabdian dan Kewirausahaan. 2 (1): 1-9.

Yulianto, H. 2017. Kajian Penerapan Financial Quotient Pada Wirausaha Pemula. Jurnal Equity. Juni. 12 (1): 48-62. $\quad$ http://ojs.stkipypup.ac.id/index.php/equity/issue/vie w/6/Harry\%20Yulianto

Yulianto, H., \& Iryani. 2018. Penilaian Kelayakan Usulan Bantuan Permodalan: Studi Kasus Pada Wirausaha Pemula di Kota Makassar. Seminar Nasional Hasil Penelitian \& Pengabdian Kepada Masyarakat (SNP2M) 2018. pp.197-202. http://jurnal.poliupg.ac.id/index.php/s np $2 \mathrm{~m} /$ article/view/882

$\begin{array}{lr}\text { KUKM. 2018. Keputusan Deputi } & \text { Bidang } \\ \text { Pembiayaan } & \text { Nomor } \\ \text { 08/KEP/DEP.2/II/2018 } & \text { Tentang } \\ \text { Petunjuk Teknis Pelaksanaan } \\ \text { Bantuan Pemerintah r Bagi } \\ \text { Wirausaha Pemula Tahun 2018. } \\ \text { Jakarta: Kementerian Koperasi dan } \\ \text { Usaha Kecil dan Menengah. }\end{array}$

Yulianto, H. 2016. Telaah Implementasi Petty Cash (Studi Kasus Pada UMKM Di Kota Makassar). Jurnal Equity. Juni. 10 (1): 33-45. http://ojs.stkip- 
ypup.ac.id/index.php/equity/issue/vie w/10/Harry $\% 20$ Yulianto 16

Yulianto, H., \& Iryani. 2018. An Effect of Enterprises Sector, Time Period, Capital Turnover, Character, and Enterprises Asset on The Feasibility Appraisal Decision of Startup Entrepreneurs Assistance Proposal. International Conference and Call For Paper 2018. 1 (1). Agustus 2018. STIM Nitro Makassar.

http://ojs.nitromks.ac.id/index.php/fd b2018/article/view/129

KUKM. 2017. Laporan Akhir Apreisal Proposal Bantuan Pemerintah Untuk Pengembangan Koperasi Pemula Dan Wirausaha Pemula Tahun 2017. Jakarta: Kementerian Koperasi dan Usaha Kecil dan Menengah.

KUKM. 2018. Laporan Akhir Apreisal Proposal Bantuan Pemerintah Untuk Pengembangan Wirausaha Pemula
Tahun 2018. Jakarta: Kementerian Koperasi dan Usaha Kecil dan Menengah.

Yulianto, H. 2016. Statistik 1. Yogyakarta: Lembaga Ladang Kata. https://lppm.stieypup.id/images/Buku/Statistik_1.pdf

Sugiyono, 2015. Metode Penelitian Kuantitatif, Kualitatif, dan $R \& D$. Bandung: Alfabeta.

KUKM. (2018). Keputusan Deputi Bidang Pembiayaan Nomor 08/KEP/DEP.2/II/2018 Tentang Petunjuk Teknis Pelaksanaan Bantuan Pemerintah Bagi Wirausaha Pemula Tahun 2018. Jakarta: Kementerian Koperasi dan Usaha Kecil dan Menengah.

Purwinarti, T. 2018. Model Rencana Usaha Bagi Wirausaha Pemula Kecil dan Menengah. Epigram. 8: 124-130. 